\title{
Measuring Market Power as Competition Over Time
}

\author{
Michael L. Marlow and George E. Wright
}

This paper suggests that the empirical measurement of market structure, particularly the reliance on concentration indexes as an indicator of noncompetitive market power, does not adequately reflect recent advances in theory. This paper integrates the literature of the interaction between market structure and firm behavior with dynamic measures of structure. Our estimation for the savings and loan industry suggests that continued application of traditional static measures in market structure-performance studies are apt to be misleading. We call for more investigation into measures of dynamic structure.

\section{Introduction}

While market structure affects market performance, empirical studies have not always found a relationship between indicators of performance (e.g., profitability) and market structure, as represented by indexes of concentration. ${ }^{1}$ Yet such indexes play a prominent role in antitrust regulation. Antitrust policy, then, faces two problems: doubt as to whether concentrated industries actually perform poorly, and a lack of criteria for choosing from among alternative indexes. $^{2}$

One reason for these problems is that empirical measures of market structure, especially indexes of concentration, have not kept up with the theory of industrial organization. While recent studies emphasize the dynamic evolution of markets as the key to predicting firm behavior and market outcomes, empirical measures of concentration typically focus on static market structure at one point in time.

While empirical research can incorporate some of these dynamic elements in an ad hoc way, regulation concerning mergers and acquisitions tends to rely on simple, standardized indicators of concentration. We argue that such indicators may have misleading implications for public policy.

Using the savings and loan industry as an example, this paper seeks to integrate the literature of the interaction between market structure and firm behavior with dynamic measures of market structure. Section $\Pi$ summarizes the literature on traditional measures of

Michael L. Mariow is from the U.S. Department of Treasury and George E. Wright is from SysteMetrics.

The views expressed are those of the authors alone and do not necessarily represent those of the U.S. Department of the Treasury or SysteMetrics. We have benefitted from comments of anonymous referees.

Address reprint requests to Michael L. Marlow, Department of the Treasury, Washington, D.C. 20220.

'See Scherer (1980) and Shepherd (1979) for summaries of the literature; Collins and Preston (1969) and Heggestad (1979) for examples of weak or nonexistent relations.

See Adelman (1969) and White (1982). 
structure, and Section III discusses previously-used measures of dynamic structure. Section IV presents first approximations of dynamic measures of market structure. Results of estimations of the market structure-profitability relation with both static and dynamic structure measures are in Section V. Section VI closes with public policy implications and recommendations for future research.

\section{Traditional Measures of Concentration and Market Structure}

In seeking to tie industrial performance to market structure, early work with simple-sum concentration ratios led to full-distribution measures-notably the entropy, HirschmanHerfindahl and Hall-Tideman indexes. Indeed, the Justice Department adopted the Hirschman-Herfindahl Index as the "official" measure of concentration on the grounds that its consideration of all firms and disproportional weighting of large-share firms "probably accords with their relative importance in any collusive interaction." (U.S. Department of Justice 1982, p. 17) The Justice Department's merger guidelines establish fixed cut-off values of 1000 and 1800 with industries below or above these values respectively classified as "unconcentrated" and "highly concentrated." Recent clarification of Justice Department policy has strengthened the use of the 1800 cut off value of the Hirschman-Herfindahl index in the evaluation of bank mergers and acquisitions. ${ }^{3}$

Despite this use of concentration indexes in regulatory policy, studies of the relationship between structure and performance have not found a consistent relationship between performance and concentration. In financial markets, a survey by Heggestad (1979) concludes that "The concentration-profitability relationship in banking has been found to be quite weak, which is surprising, since many studies find that price and non-price competition is affected by concentration." Evidence for the traditional hypothesis of a direct relation between concentration and profitability may be found in Edwards (1965), Kaufman (1966), Verbrugge and Shick (1976), and Heggestad (1977). Contrasting evidence is presented in Bryan (1972), Ware (1972), and Yeats (1974).

One possible reason for the lack of a strong empirical relationship between concentration and profitability is that the indexes used to measure market structure may fail to capture the dynamic evolution of a market. In "creative destruction," (Schumpeter 1950; Nelson and Winter 1982), the process whereby innovators challenge the market power of dominant firms depends not so much on a dominant firm's share, but on how fast that share is eroded. The emphasis on entry barriers in Bain (1956) views market power as a function of the ability to maintain noncompetitive structure over time. One implication of the empirical literature on entry barriers is that a snapshot picture of different markets at one point in time may be able to explain entry as a function of barriers, yet there may be no simple relation between performance measures (e.g., profitability) and existing static market structure. For example, a concentrated market may exhibit high or low profitability depending upon whether or not its members have had to allocate resources to resist entry efforts.

The importance of changes in market structure is strengthened by the findings of Shepherd (1979) and others who find that profitability of individual firms is more a function of their own market than the average characteristics of the market as a whole. ${ }^{4}$ The importance of firm

\footnotetext{
${ }^{3}$ The original guidelines allowed possibility of challenges to post-merger Hirschman-Herfindahl scores of less than 1800. In banking markets, however, this rarely occurred, and an additional criterion of an increase is at least 200 points has further limited the scope of challengers. High index scores by themselves do not constitute the only grounds for regulatory challenge. (Kolatch 1985; Burke 1984)

${ }^{4}$ See Shepherd (1979, Ch. 13) for a review of these studies. More recent research by Schmalensee (1985) has, however, suggested that characterizations of the market as a whole may be very important.
} 
shares also implies that changes in relative position are crucial in determining performance. ${ }^{5}$ Emphasis on the individual firm's position in the market has fostered research on the relation between intra-market strategic group concentration and performance. ${ }^{6}$ That is, behavior depends both on average concentration, and the degree to which smaller "outgroup" members can challenge the members of the dominant oligopoly core. ${ }^{7}$

The "uprising" theory of contestable markets in Baumol (1982) argues that free entry and exit are the prime determinants of contestability. Actual and potential entrants, not the lack of concentration in market shares, discipline incumbents. Among financial institutions, an existing firm may suddenly change behavior and act like one of Baumol's "hit-and-run" raiders. ${ }^{8}$ Merger with another firm, acquisition by a holding company, or a sudden shift in management can lead a small firm to challenge the position of the dominant oligopoly core.

In the same vein, Brozen's (1982) survey of concentration and performance attacks the "naive" notion that the number of firms or the distribution of market shares has consistent effect on the performance of an industry. Brozen (1982) argues that social costs and benefits of concentration can be evaluated only by tracing the evolution of market performance over time.

\section{Dynamic Measures of Concentration}

Despite the theoretical emphasis on evolution over time as the key to performance and scattered calls for dynamic measures of market structure, there has been little empirical work to operationalize the approach.$^{9}$ In financial markets, a few papers have examined empirical relations between changes in measures of market structure and performance. Graddy (1980) finds that, regardless of initial levels of structure, changes in deposit shares of dominant firms are important determinants of performance. Marlow (1983a) finds that increases in both de novo and branching entry by commercial banks and savings and loans improve performance. More important in terms of measuring concentration, Rose and Fraser (1976) find no evidence of a relation between performance and changes in simple-sum concentration, Herfindahl, or share stability indexes.

Simply measuring the net change in existing static indexes is unlikely to capture the key evolutionary aspects of market structure. An index which seeks to summarize the degree of anticompetitive potential should reflect dynamic aspects. An adequate measure should represent the degree of active competition among firms for top positions in a market. While competition may be affected by the size of market share held by the largest firms, the potential for movement in and out of the top positions is of primary importance to competitive behavior. Such indicators of competitive structure are "dynamic," as opposed to comparative-static indexes of concentration. ${ }^{10}$

\section{First Approximations of Dynamic Structure}

We consider two dynamic measures of structure: mobility and turnover over specified time periods. These measures are dynamic, in that different positionings or orderings of

${ }^{5}$ The authors are indebted to Professor William Shepherd for this observation.

${ }^{6}$ See Newman (1978), Porter (1979), and Allen (1983).

${ }^{7}$ See Scott (1980) for some evidence suggesting the importance of this effect.

${ }^{8}$ See Caves and Porter (1977).

${ }^{9}$ We discuss the many problems with current popular indices in Marlow and Wright (1986).

${ }^{10}$ These measures of "dynamic"' structure have been discussed before; e.g., see Scherer (1980, p. 73-76). 
competitors over time are associated with different levels of competition. The following definitions (with respect to deposit volume) are used. ${ }^{11}$ Mobility $(M)$ is the number of changes in rank that occur among the three largest firms in a SMSA. Turnover $(T)$ measures the number of times that firms below the top three move into the top three in a SMSA.

We argue that a large change in the rank ordering of firms reflects a high level of competition that ultimately reduces profitability. This argument implies one-way casuality which runs from our measures of competitive structure to profitability. Whether or not such confrontations over market share result from declining or increasing total market strength, the actions of aggressive management in a stable market or just basic instinctive behavior really do not affect the argument. The important issue is that challenges to the dominant firms are crucial to the measurement of competition.

There are two potential problems with our measurement of market power. Similar measures of mobility and turnover have been applied in market structure-performance studies of financial markets. However, they have always been employed as performance (dependent) variables. ${ }^{12}$ Heggestad and Rhoades (1976), Rhoades (1980), and Rhoades and Rutz (1981) use data for commercial banks, while Marlow (1983b) and Marlow, Link and Trost (1984) use data for savings and loans. While mobility and turnover are inversely correlated with profitability (Marlow 1983b), the question of whether these variables are endogenous or exogenous has not been specifically addressed in the literature. However, since conventional microeconomics argues that competition affects profitability, it seems reasonable to assume that our dynamic measures of competitiveness are exogenous determinants of profitability.

Causality from profitability to dynamic structure measures would imply that our structure measures are endogenous. For example, firms operating with low profits could reduce their operating size, thus affecting the magnitude of our measures of structure. We cannot dismiss the possibility that causality could run both ways. ${ }^{13}$ However, this issue is equallty pertinent to the modeling of traditional relations between performance and market structure. Placing our measures on the right-hand side of the equation does not prove that they are exogenous. However, antitrust regulation assumes that high levels of concentration cause noncompetitive behavior. Exploration of a simultaneous determination of market structure is left for future research.

\section{Estimation of Market Structure-Profitability Relations}

The empirical model, which is estimated by a linear regression model with 124 observations, is

$$
P=f\left(\mathrm{MS}_{s} \text { or } \mathrm{MS}_{D}, O P E X, L I Q, P C Y, P P, C B P, D 1, D 2\right)
$$

${ }^{11}$ We have also used five firms, in place of three, as the cut off number for these definitions but this does not alter the results below.

${ }^{12}$ Studies using mobility and turnover measures in nonfinancial markets include Kaplan (1954), Friedland (1957), Hymer and Pashigian (1962), and Boyle and Sorenson (1971). However, due to limited availability of microdata, they tend to estimate market structure-performance relations for large groupings of industries.

${ }^{13}$ One may be able to describe circumstances that suggest opposite causality from the direction assumed here. For example, those SMSAs with relatively low profits may represent SMSAs where exogenous shocks have hit large firms that represent large numbers in the market profit data. In this case, it is possible that their depressed profits lower the market figure and, consequently, this exogenous profit shock would produce negative signs on the coefficients on mobility and turnover. 
where:

$P=$ net income before taxes/total assets in $1979^{14}$

$\mathrm{MS}_{S}$ : static measures of market structure

$=C R 3=3$-firm concentration ration in $1979^{15}$

$=H=$ Herfindahl index in 1979

$\mathrm{MS}_{D}$ : dynamic measures of market structure

$=D C R 3=$ change in $C R 3$ from 1977-1979

$=D H=$ change in $H$ from 1977-1979

= M3 = mobility among 3 largest firms for 1976-1979

$=T 3=$ turnover among 3 largest firms for 1976-1979

$O P E X=$ operating expenses [(office occupancy + salaries + advertising $) /$ total assets in 1979$]^{16}$

$L I Q=$ cash and investment securities/total assets in 1979

$P C Y=$ per capita income in 1979

$P P \quad=$ percentage change in population from 1970-1979

$C B P=$ number of commercial banks per capita in 1979

$D 1=1$, if SMSA is in the West,

$=0$, otherwise, and

$D 2=1$, if SMSA is in the East,

$=0$, otherwise.

Firm data, except $C B P$, are for all insured savings and loans for a cross section of 124 SMSAs over the period 1976-1979. ${ }^{17}$ The choice of the 124 SMSAs is based solely on data availability and the criterion that each SMSA has more than five savings and loans in $1979 .{ }^{18}$ A cut-off of three firms is necessary due to the definition of $T$ : with less than four firms, $T$ must always be zero. Therefore, for SMSAs with less than four firms, the value of $T=0$ does not provide a measure of economic significance. ${ }^{19}$ The reduced-form of Equation (1) is chosen since it is consistent with previous studies and provides estimation of the net effects of explanatory variables on profitability. ${ }^{20}$

${ }^{14}$ An alternative measure of profitability (net income/total assets) did not substantially alter the results below.

${ }^{15}$ Due to space limitations, only $C R 3$ is displayed here. However, one-to-five firm concentration ratios were used and all of these yielded the same results when estimated in Equation 1.

${ }^{16}$ It is noted that in a detailed simultaneous model, OPEX may be endogeneously determined with $P$.

${ }^{17}$ Data on savings and loans obtained from Summary of Savings Accounts by Geographic Area and unpublished reports of the Federal Home Loan Bank Board. Other data are obtained from Summary of Accounts and Deposits, and Statistical Abstract of the United States.

${ }^{18}$ The original sample consisted of 153 SMSAs. However, due to various data omissions and the requirement that each SMSA have more than three firms, the final sample consists of 124 SMSAs. The following points suggest that there exists little potential for serious sample selection bias. The chosen sample represents a relatively large sample when considered in the context of previous studies of the savings and loan industry. For example, see Marlow (1982) with 111 SMSAs and Marlow, Link, and Trost (1984) with 99 SMSAs. Moreover, the number of SMSAs with three or fewer firms is only 15 out of the original sample of 153 SMSAs; the other deletions from the sample result from omissions of other data, Finally, running the regressions without the restriction that there must be at least three firms per SMSA (139 SMSAs) does not generate significant changes in the coefficients and significant levels in any independent variable.

${ }^{19}$ This issue is discussed in Marlow, Link, and Trost (1984).

${ }^{20}$ For previous studies of profitability in the savings and loan industry, see Verbrugge and Shick (1976), Verbrugge, Shick, and Thygerson (1976), Spellman (1981) and Marlow (1983c). 
Profitability $P$ is measured as net income before taxes/total assets. Static and dynamic measures of market structure $\left(\mathrm{MS}_{S}\right.$ and $\mathrm{MS}_{D}$ ) are used to measure the impacts of structure on profitability. Static measures are the three-firm concentration ratio $C R 3$ and the Herfindahl index $H$. Dynamic measures are changes in the traditional static measures $D C R 3$ and $D H$ and our suggested dynamic measures $M$ and $T$. Due to data availability, $D C R 3$ and $D H$ are for the period 1977-1979 and $M$ and $T$ are for 1976-1979. Past studies have expected a positive relation to exist between static measures $(C R 3$ and $H)$ and profitability $P$.

Past studies have expected positive relations between profitability and changes in static measures $D C R 3$ and $D H$; however, we argued above that, similar to the problems associated with $C R 3$ and $H$, these measures may not be expected to have a significant influence on profitability. Mobility $M$ and turnover $T$ should be negatively related to profitability.

Operating expenses $O P E X$ should be negatively related to profitability. Cash and investment securities divided by assets, $L I Q$ is a measure of liquidity and should exert a negative effect on profitability. Demand variables $P C Y$ and $P P$ should be positively related to profitability.

The number of commercial banks per capita $C B P$ are controlled because they compete with savings and loans for deposits. ${ }^{21}$ To a lesser extent, commercial banks also compete with savings and loans in various loan markets. Because greater numbers of commercial banks per capita should exert stronger competitive forces in markets, a negative relation between $C B P$ and profitability is expected. ${ }^{22}$

Dummies $D 1$ (West Coast) and D2 (East Coast) control regional differences in profitability. These may include age of loan portfolio and differences in income and population growth. For example, faster growth on the West Coast may be reflected in younger loan portfolios for the West Coast with higher yields. In addition, more rapid population and income growth on the West Coast should exert relatively favorable impacts on profitability. For these reasons $D 1$ and $D 2$ should carry positive and negative signs, respectively. ${ }^{23}$

Table 1 displays the regression results for equations with static measures of market structure, with and without regional dummies. Operating costs $O P E X$ exert negative and statistically significant impacts on profitability for the equations with the regional dummies. Liquidity $L I Q$ exerts a negative and statistically significant impact on profitability for the equations without the regional dummies. When statistically significant, both $O P E X$ and $L I Q$ exhibit the expected signs. Per capita income PCY never exerts an effect statistically different from zero. For the equations without regional dummies, population growth PP exerts the expected positive and statistically significant impact on profitability. The impact from commercial banks per capita $C B P$ is never statistically different from zero. Both dummies $D 1$ and $D 2$ carry expected and statistically significant signs. Inclusion of the dummies cancels the effects of $L I Q$ and $P P$ on profitability and suggests that their effects are captured in regional

${ }^{21}$ An alternative measure, commercial banks unscaled by population, had an effect on profitability that was consistently insignificant from zero, and did not significantly alter the other variables' coeffcients and significance levels.

${ }_{22}$ This expectation is consistent with the studies Kaufman (1966), Rhoades (1979). Spellman (1981), and Marlow (1982) which find competitive interactions between savings and loans and commercial banks in estimations of market structure-performance relations.

${ }^{23}$ As pointed out by a referee, continuous variables are preferable to dichotomous when it is unlikely that effects are not uniform across broad regions of the country. However, in our study we expect that several variables may be successfully measured on a broad regional basis. For example, firm portfolio composition and growth, demographics of the population and exogenous shocks such as oil "crises" all affect housing demand and finance on a regional basis. For simplicity, we chose to measure the general intluence of these variables on profitability through dichotomous measures rather than separate continuous measures. Moreover, such measurement is within our resources. 
Table 1. Regression Results for Equations with Static Market Structure ( $T$-Statistics Are Shown Below Estimated Coefficients)

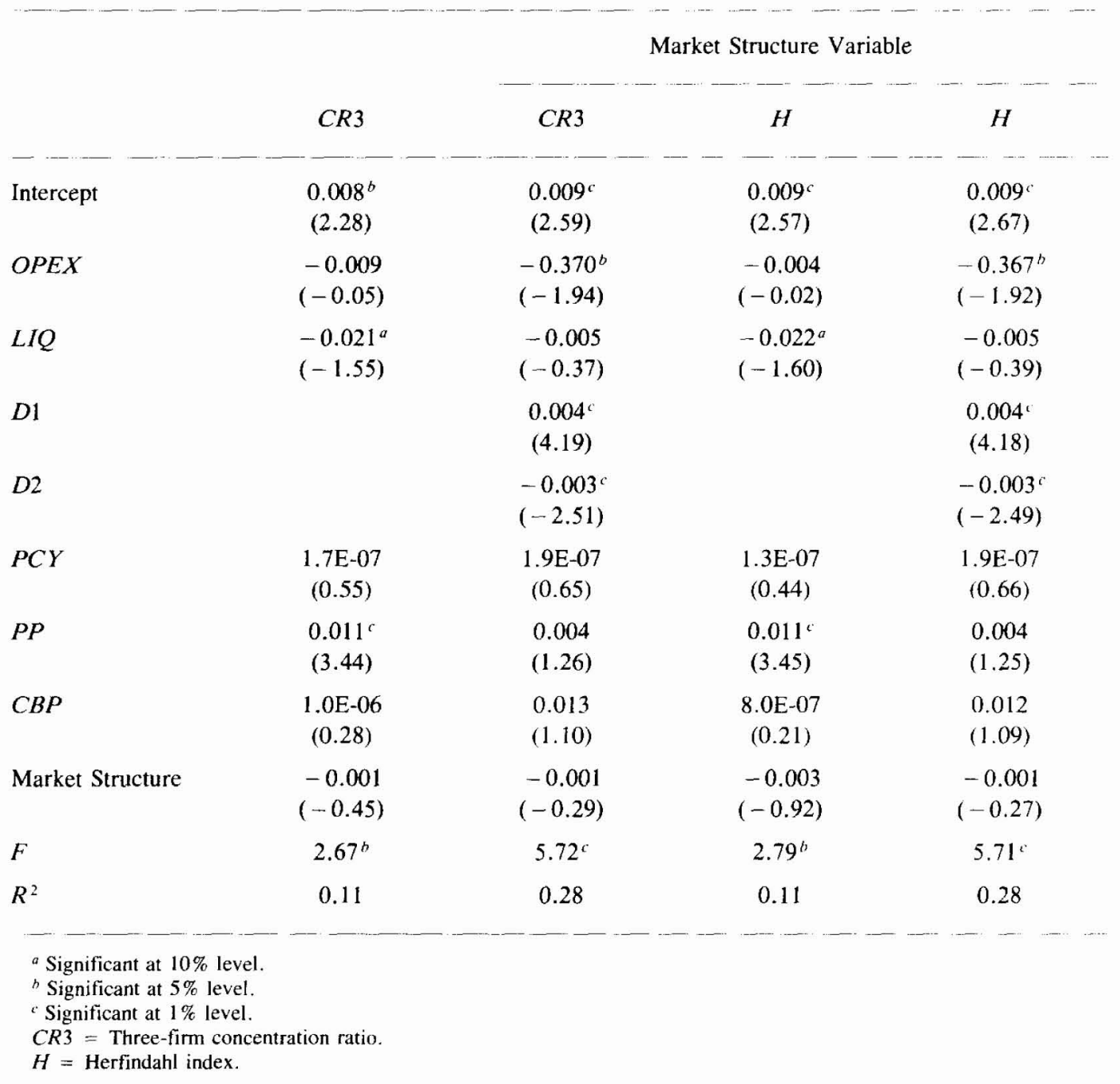

differences. Static measures of structure, $C R 3$ or $H$, never exert impacts on profitability that are significantly different from zero.

Table 2 displays the regression results for equations with dynamic measures of market structure. The results for $O P E X, L I Q, D 1, D 2, P C Y$, and $P P$ mirror the results displayed in Table 1. Commercial banks per capita $C B P$ displays a positive and statistically significant sign in only two of eight equations. While the sign is contrary to expectations, the significance level is only $10 \%$ in those two cases. Neither of the changes in static measures $D C R 3$ or $D H$ display an effect statistically different from zero. However, both of our dynamic measures $M$ and $T$ exert the expected negative and statistically significant impacts on profitability for equations with and without the regional dummies. ${ }^{24}$

${ }^{24}$ One referee has suggested that by definition, mobility and turnover will tend to be higher, simply by chance, when the number of firms in an industry is large. Consequently, our results may indicate that profits fall as the number of firms in the market increases. However, additional tests indicate that the number of firms is not important per se. Replacing our selected measures of competition with various measures of number of firms (number of savings and loans per capita and number of savings and loans) did not indicate any significant influence on profitability. In addition, simple correlation coefficients between mobility and turnover and the number of firms proved to be not significantly different from zero. 
Table 2. Regression Results for Equations with Dynamic Market Structure ( $T$-Statistics Are Shown Below Estimated Coefficients)

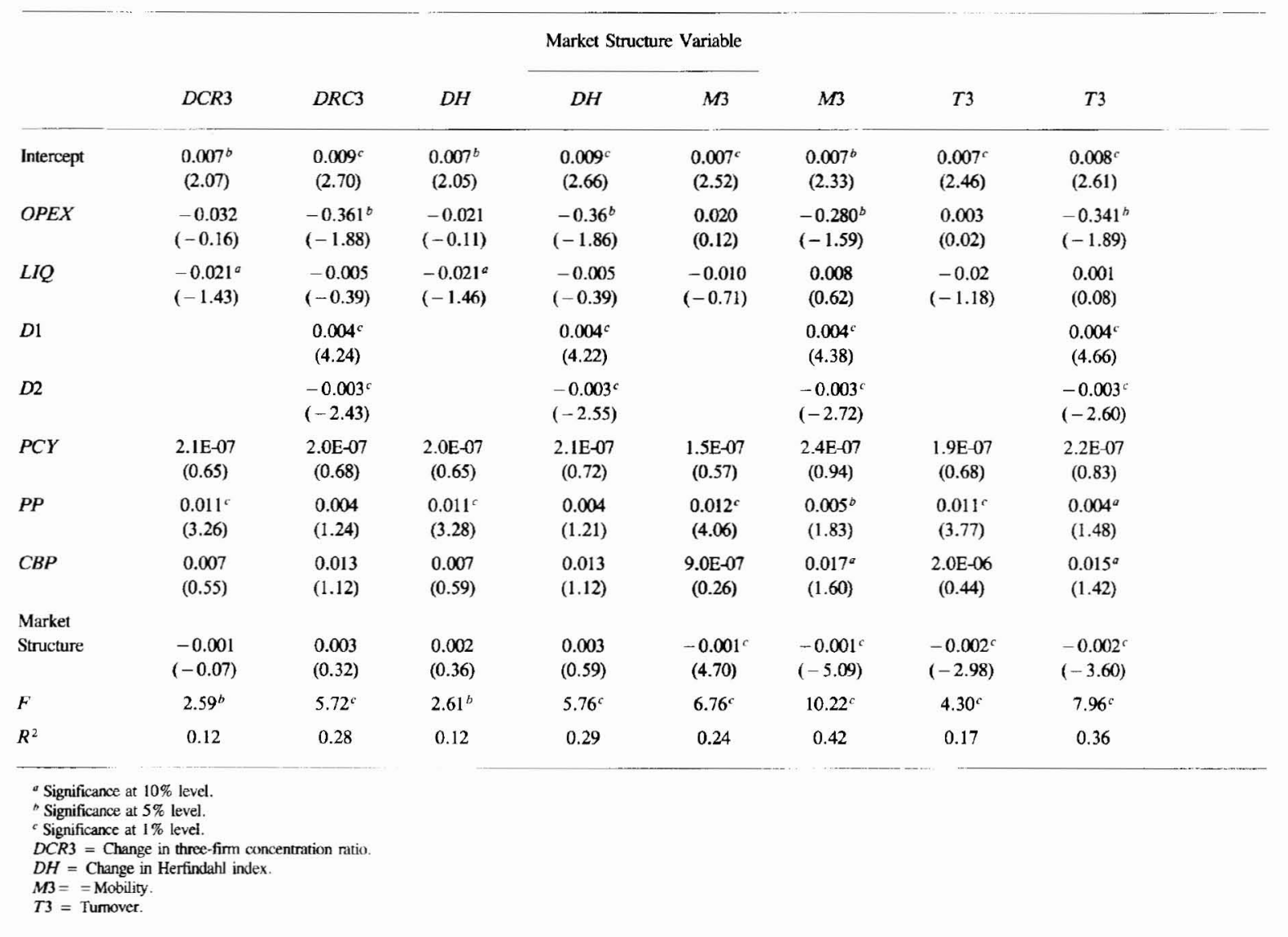


Tables 3 and 4 display the regression results for equations which include both static and dynamic measures of market structure, to control for the ability of firms to alter market positions. That is, competition may be affected by the size of market shares of the largest firms. Static measures of structure reflect the traditional hypothesis that they reflect the monopoly power of firms which, in turn, influences the ability of firms to alter market positions and ultimately their profitability. Dynamic measures reflect the recent level of structural change in the market. For reasons of brevity, only those equations including the regional dummies are displayed; however, the results mirror the results displayed in Tables 1 and 2 for equations with and without regional dummies.

In no case do the static measures of structure ( $C R 3$ and $H$ ) exert an impact on profitability which is statistically different from zero. Neither of the changes in static measures of structure ( $D C R 3$ and $D H$ ) display statistically significant impacts on profitability. As in Tables 1 and

Table 3. Regression Results for Equations with Static and Dynamic Market Structure ( $T$-Statistics Are Shown Below Estimated Coefficients)

\begin{tabular}{|c|c|c|c|c|}
\hline & & & Static: $C R 3$ & \\
\hline & $D C R 3$ & $D H$ & $M 3$ & $T 3$ \\
\hline Intercept & $\begin{array}{l}0.009^{c} \\
(2.57)\end{array}$ & $\begin{array}{l}0.009^{c} \\
(2.57)\end{array}$ & $\begin{array}{l}0.008^{c} \\
(2.55)\end{array}$ & $\begin{array}{l}0.009^{c} \\
(2.68)\end{array}$ \\
\hline$O P E X$ & $\begin{array}{l}-0.362^{b} \\
(-1.87)\end{array}$ & $\begin{array}{l}-0.356^{b} \\
(-1.85)\end{array}$ & $\begin{array}{l}-2.73^{a} \\
(-1.57)\end{array}$ & $\begin{array}{l}-0.341^{b} \\
(-1.88)\end{array}$ \\
\hline$L I Q$ & $\begin{array}{l}-0.005 \\
(-0.38)\end{array}$ & $\begin{array}{l}-0.005 \\
(-0.38)\end{array}$ & $\begin{array}{l}0.009 \\
(0.68)\end{array}$ & $\begin{array}{l}0.001 \\
(0.11)\end{array}$ \\
\hline$D 1$ & $\begin{array}{l}0.004^{c} \\
(4.16)\end{array}$ & $\begin{array}{l}0.004^{c} \\
(4.14)\end{array}$ & $\begin{array}{l}0.003^{c} \\
(4.22)\end{array}$ & $\begin{array}{l}0.004^{c} \\
(4.54)\end{array}$ \\
\hline$D 2$ & $\begin{array}{l}-0.003^{c} \\
(-2.44)\end{array}$ & $\begin{array}{l}-0.003^{c} \\
(-2.56)\end{array}$ & $\begin{array}{l}-0.003^{c} \\
(-2.79)\end{array}$ & $\begin{array}{l}-0.003^{c} \\
(-2.63)\end{array}$ \\
\hline$P C Y$ & $\begin{array}{c}1.8 \mathrm{E}-07 \\
(0.62)\end{array}$ & $\begin{array}{c}1.9 \mathrm{E}-07 \\
(0.64)\end{array}$ & $\begin{array}{c}1.9 E-07 \\
(0.72)\end{array}$ & $\begin{array}{c}1.8 \mathrm{E}-07 \\
(0.67)\end{array}$ \\
\hline$P P$ & $\begin{array}{l}0.004 \\
(1.26)\end{array}$ & $\begin{array}{l}0.004 \\
(1.24)\end{array}$ & $\begin{array}{l}0.006^{b} \\
(1.99)\end{array}$ & $\begin{array}{l}0.005^{a} \\
(1.58)\end{array}$ \\
\hline$C B P$ & $\begin{array}{l}0.013 \\
(1.12)\end{array}$ & $\begin{array}{l}0.013 \\
(1.13)\end{array}$ & $\begin{array}{l}0.017^{a} \\
(1.64)\end{array}$ & $\begin{array}{l}0.016^{a} \\
(1.44)\end{array}$ \\
\hline Static $C R 3$ & $\begin{array}{l}-0.004 \\
(-0.26)\end{array}$ & $\begin{array}{c}-0.001 \\
(-0.33)\end{array}$ & $\begin{array}{l}-0.002 \\
(-1.04)\end{array}$ & $\begin{array}{l}-0.001 \\
(-0.74)\end{array}$ \\
\hline $\begin{array}{l}\text { Dynamic Market } \\
\text { Structure }\end{array}$ & $\begin{array}{l}0.002 \\
(0.29)\end{array}$ & $\begin{array}{l}0.004 \\
(0.61)\end{array}$ & $\begin{array}{l}-0.001^{c} \\
(-5.19)\end{array}$ & $\begin{array}{l}-0.002^{c} \\
(-3.65)\end{array}$ \\
\hline$F$ & $5.05^{c}$ & $5.09^{c}$ & $9.21^{c}$ & $7.11^{\mathrm{c}}$ \\
\hline$R^{2}$ & 0.29 & 0.29 & 0.42 & 0.36 \\
\hline $\begin{array}{l}\text { a Significance at } 1 \\
\text { b Significance at } 5 \\
\text { c Significance at } 1 \\
C R S=\text { Three-firn } \\
D C R 3=\text { Change } \\
M 3=\text { Mobility. } \\
T 3=\text { Turnover. }\end{array}$ & ation ratio. & & & \\
\hline
\end{tabular}


Table 4. Regression Results for Equations with Static and Dynamic Market Structure ( $T$-Statistics Are Shown Below Estimated Coefficients)

\begin{tabular}{|c|c|c|c|c|}
\hline & & & Static: $H$ & \\
\hline & $D C R 3$ & $D H$ & $M 3$ & $T 3$ \\
\hline Intercept & $\begin{array}{l}0.009^{\circ} \\
(2.66)\end{array}$ & $\begin{array}{l}0.009 \\
(2.65)\end{array}$ & $\begin{array}{l}0.008^{c} \\
(2.46)\end{array}$ & $\begin{array}{l}0.009^{\circ} \\
(2.63)\end{array}$ \\
\hline OPEX & $\begin{array}{l}-0.360^{b} \\
(-1.86)\end{array}$ & $\begin{array}{l}-0.352^{h} \\
(-1.83)\end{array}$ & $\begin{array}{l}-0.266^{a} \\
(-1.53)\end{array}$ & $\begin{array}{l}-0.337^{b} \\
(-1.85)\end{array}$ \\
\hline$L I Q$ & $\begin{array}{l}-0.006 \\
(-0.40)\end{array}$ & $\begin{array}{l}-0.006 \\
(-0.41)\end{array}$ & $\begin{array}{l}0.008 \\
(0.59)\end{array}$ & $\begin{array}{l}0.001 \\
(0.05)\end{array}$ \\
\hline$D 1$ & $\begin{array}{l}0.004 \\
(4.14)\end{array}$ & $\begin{array}{l}0.004 \\
(4.12)\end{array}$ & $\begin{array}{l}0.003 \\
(4.22)\end{array}$ & $\begin{array}{l}0.004^{c} \\
(4.55)\end{array}$ \\
\hline$D 2$ & $\begin{array}{l}-0.003^{c} \\
(-2.42)\end{array}$ & $\begin{array}{l}-0.003 \\
(-2.54)\end{array}$ & $\begin{array}{l}-0.003^{c} \\
(-2.70)\end{array}$ & $\begin{array}{l}-0.003 \\
(-2.58)\end{array}$ \\
\hline$P C Y$ & $\begin{array}{c}1.8 \mathrm{E}-07 \\
(0.63)\end{array}$ & $\begin{array}{c}1.9 \mathrm{E}-07 \\
(0.65)\end{array}$ & $\begin{array}{c}2.1 \mathrm{E}-07 \\
(0.79)\end{array}$ & $\begin{array}{c}2.0 \mathrm{E}-07 \\
(0.74)\end{array}$ \\
\hline$P P$ & $\begin{array}{l}0.004 \\
(1.26)\end{array}$ & $\begin{array}{l}0.004 \\
(1.24)\end{array}$ & $\begin{array}{l}0.006^{b} \\
(1.92)\end{array}$ & $\begin{array}{l}0.005^{a} \\
(1.52)\end{array}$ \\
\hline$C B P$ & $\begin{array}{l}0.013 \\
(1.11)\end{array}$ & $\begin{array}{l}0.013 \\
(1.12)\end{array}$ & $\begin{array}{l}0.017^{a} \\
(1.61)\end{array}$ & $\begin{array}{l}0.015^{a} \\
(1.42)\end{array}$ \\
\hline Static $H$ & $\begin{array}{l}0.001 \\
(-0.24)\end{array}$ & $\begin{array}{l}-0.001 \\
(-0.35)\end{array}$ & $\begin{array}{l}-0.002 \\
(-0.83)\end{array}$ & $\begin{array}{l}-0.001 \\
(-0.47)\end{array}$ \\
\hline $\begin{array}{l}\text { Dynamic Market } \\
\text { Structure }\end{array}$ & $\begin{array}{l}0.002 \\
(0.29)\end{array}$ & $\begin{array}{l}0.004 \\
(0.63)\end{array}$ & $\begin{array}{l}-0.001^{c} \\
(-5.14)\end{array}$ & $\begin{array}{l}-0.002^{c} \\
(-3.61)\end{array}$ \\
\hline$F$ & $5.05^{c}$ & $5.10^{c}$ & $9.14^{c}$ & $7.05^{\circ}$ \\
\hline$R^{2}$ & 0.29 & 0.29 & 0.42 & 0.36 \\
\hline
\end{tabular}

2, the coefficients on $M$ and $T$ display negative signs which are statistically different from zero at the 0.01 level or better. Therefore, controlling traditional measures of concentration does not appear to influence the effects of mobility and turnover on profitability.

\section{Conclusion and Avenues for Future Research}

Our message is that levels and changes in static indicators of concentration may offer misleading measures of market competition. In the savings and loan idustry, it may not matter much if the largest firms have a large market share, as long as there is active competition among them for position and/or there is potential movement in and out of the top three positions. 
A policy implication is that traditional static measures of structure in market structureperformance studies are apt to be misleading. The implication for the usefulness of recent work in developing full-distribution static indexes also carries the same conclusion. These implications follow from the problems of standardization and interpretation associated with the various static measures of concentration. The empirical findings of this paper support recent theoretical research which argues that challenges to the dominant core of firms from de novo entrants and existing outgroup members is of primary importance to the maintenance of market power. The implication for regulatory analysis is that more research should be directed at studying dynamic structure measures when considering applications for mergers, acquisitions, or de novo entry.

We suggest two possible avenues for future research. One, further development of measures of dynamic structure will aid our understanding of how evolving market processes affect market performance. At best, our measures of dynamic structure are first approximations and could be improved by developing full distribution measures which exclude arbitrary numbers of firms considered (e.g., largest five) and are standardized for differing numbers of firms in small markets. Two, research on the relations between static and dynamic measures of structure is needed. Such research could provide more information on the relative usefulness of static and dynamic measures in formulating public policy.

\section{References}

Adelman, M.A. Feb. 1969. Comment on the ' $H$ ' concentration measure as a numbers equivalent. Review of Economics and Statistics 51:99-101.

Allen, R. April 1983. Efficiency, market power and profitability in American manufacturing. Southern Economic Journal 49:933-940.

Bain, J. S. 1956. Barriers to New Competition. Cambridge: Harvard University Press.

Baumol, W. J. March 1982. Contestable markets: An uprising in the theory of structure. American Economic Review 72:1-15.

Boyle, S. E., and Sorenson, R. L. April 1971. Concentration and mobility: Alternative measures of industry structure. Journal of Industrial Economics. 19:118-132.

Brozen, Y. 1982. Concentration, Mergers, and Public Policy. New York: Macmillan.

Bryan, W. R. 1972. The determinants of bank profits. Research Paper No. 8, American Bankers Association, Washington, D.C.

Burke, J. June 1984. Antitrust laws, justice department guidelines, and the limits of concentration in local markets, Staff Studies, Board of Governors of the Federal Reserve System, Wash. D.C.

Caves, R. E., and Porter, M. E. May 1977. From entry barriers to mobility barriers: Conjectural decisions and contrived deterrance to new competition. Quarterly Journal of Economics 91:241-61.

Collins, N., and Preston, L. E. Aug. 1969. Price cost margins and industry structure. Review of Economics and Statistics 51:271-286.

Edwards, F. R. Sept. 1965. The banking competition controversy. National Banking Review 3:134.

Federal Home Loan Bank Board, Summary of Savings Accounts by Geographic Area (1979).

Friedland, S. Feb. 1957. Turnover and growth of the largest industrial firms, 1906-1950. Review of Economics and Statistics 39:79-83.

Graddy, Duane B. Summer 1980. The measurement of market structure and its influence on bank prices and profitability. Nebraska Journal of Economics and Business 19:41-54.

Heggestad, A. A., and Rhoades, S. A. Nov. 1976. Concentration and firm stability in commercial banking. Review of Economics and Statistics 58:443-452. 
Heggestad, A. A. Sept. 1977. Market structure, risk and profitability in commercial banking. Journal of Finance 32:1207-1216.

Heggestad, A. A. 1979. A survey of studies on banking competition and performance. Issues in Financial Regulation. F. R. Edwards, ed. New York: McGraw-Hill.

Hymer, S., and Pashigian, P. Feb. 1962. Turnover of firms as a measure of market behavior. Review of Economics and Statistics 44:82-87.

Kaplan, A. D. 1954. Big Enterprise in a Competitive Society. Brookings Institution, Washington, D.C.

Kaufman, G. C. April 1966. Bank market structure and performance: The evidence from Iowa. Southern Economic Journal 32:429-439.

Kolatch, Barry S. April, 1985. New DOJ bank merger policy: An appraisal. Banking Expansion Reporter 4:1, 11-13.

Marlow, M. L. 1982. Bank structure and mortgage rates: Implications for interstate banking. Journal of Economics and Business 34:135-142.

Marlow, M. L. Fall 1983a. Entry and performance in financial markets. Journal of Bank Research 14:227-230.

Marlow, M. L. July 1983b. Market structure and rivalry in the savings and loan association. Housing Finance Review 3:209-223.

Marlow, M. L. Dec. 1983c. A canonical correlation analysis of savings and loan association performance. Applied Economics 15:815-820.

Marlow, M. L., Link, J. P., and Trost, R. P. Nov. 1984. Market structure and rivalry: New evidence with a nonlinear model. Review of Economics and Statistics 66:678-682.

Marlow, M. L., and Wright, G. E. 1986. Fundamental problems with popular indices of market structure. Unpublished manuscript.

Nelson, R. R., and Winter, S. G. March 1982. The Schumpeterian tradeoff revisited. American Economic Review 72:114-132.

Newman, H. H. Aug. 1978. Strategic groups and the structure-performance relation. Review of Economics and Statistics 60:417-427.

Porter, M. E. May 1979. The structure within industries and companies performance. Review of Economics and Statistics 61:214-227.

Rhoades, S. A. Fall 1979. Nonbank thrift institutions as determinants of performance in banking markets. Journal of Economics and Business 32:66-72.

Rhoades, S. A. 1980. Entry and competition in banking. Journal of Banking and Finance 4:143150.

Rhoades, S. A. and Rutz, R. D. Aug. 1981. A reexamination and extension of the relationship between concentration and firm bank stability. Review of Economics and Statistics 63:446451.

Rose, P. S., and Fraser, D. R. June 1976. The relationships between stability and change in market structure: An analysis of bank prices. Journal of Industrial Economics 24:251-266.

Scherer, F. M. 1980. Industrial Market Structure and Economic Performance, 2ed, Rand McNally Co., Chicago, Illinois.

Schmalensee, R. June 1985. Do markets differ much? The American Economic Review 75:341351.

Schumpeter, J. A. 1950. Capitalism, Socialism and Democracy, 3ed, New York: Harper and Row.

Scott, John T. Nov. 1980. Homogenizing deconcentration: Estimation and simulation. Review of Economics and Statistics 62: 612-615.

Shepherd, W. G. 1979. The Economics of Industrial Organization. Englewood Cliffs, New Jersey: Prentice Hall.

Spellman, L. J. Spring 1981. Commercial banks and the profits of savings and loan markets. Journal of Bank Research 12:32-36.

Statistical Abstract of the United States, U.S. Department of Commerce, (various years). 
Summary of Savings Accounts by Geographic Area, Federal Home Loan Bank Board, (various years).

Summary of Accounts and Deposits, Federal Deposit Insurance Corporation (various years).

U.S. Department of Justice, Merger Guidelines (June 14, 1982) and (June 14, 1984).

Verbrugge, J. A., and Shick, R. A. 1976. Market structure and savings and loan profitability. Quarterly Review of Economics and Business 16:79-90.

Verbrugge, J. A., Shick, R. A., and Thygerson, K. J. Dec. 1976. An analysis of savings and loan profit performance. Journal of Finance 31:1427-1442.

Ware, R. F. March 1972. Banking structure and performance: Some evidence from Ohio. Economic Review of the Federal Reserve Bank of Cleveland, 3-14.

White, A. P. Oct. 1982. A note on market structure measures and the characteristics of markets that they "measure." Southern Economic Journal 49:542-549.

Yeats, A. J. Winter 1974. Further evidence on the structure-performance relation in banking. Journal of Economics and Business 26:95-100. 